\title{
Comparison of Regular Atmospheric Storage versus Modified Atmospheric Packaging on Postharvest Quality of Organically Grown Lowbush and Half-Highbush Blueberries
}

\author{
Angela Koort ${ }^{1,2, *}$, Ulvi Moor ${ }^{1}$, Priit Põldma ${ }^{1}$, Clive Kaiser ${ }^{2,3}$ and Marge Starast ${ }^{1}$ \\ 1 Institute of Agricultural and Environmental Sciences, Estonian University of Life Sciences, Kreutzwaldi 1, \\ Tartu 51006, Estonia; ulvi.moor@emu.ee (U.M.); priit.poldma@emu.ee (P.P.); marge.starast@emu.ee (M.S.) \\ 2 Norwegian Institute of Bioeconomy Research, NIBIO Ullensvang, Haugasund, 5781 Lofthus, Ullensvang, \\ Hardanger, Norway \\ 3 Department of Horticulture, Oregon State University, 418 N Main St, Milton Freewater, OR 97862, USA; \\ clive.kaiser@oregonstate.edu \\ * Correspondence: angela.koort@gmail.com; Tel.: +37-256-285-766
}

Received: 14 September 2018; Accepted: 25 October 2018; Published: 28 October 2018

check for updates

\begin{abstract}
The aim of the study was to determine the effect of modified atmosphere (MA) packages on the external quality of organically grown lowbush blueberry and half-highbush blueberry ('Northblue') and the nutritional value of the fruits. Fruits were divided into plastic punnets and stored as follows: regular atmosphere (RA), punnets without packing; punnets sealed in a low-density polyethylene (LDPE, Estiko) bag; punnets sealed in an Xtend ${ }^{\oplus}$ blueberry bag (Stepac). Fruits were stored at $3 \pm 1{ }^{\circ} \mathrm{C}$. Compared to RA conditions, the $\mathrm{Xtend}^{\oplus}$ package prolonged the postharvest life for 15 days for lowbush and 9 days for half-highbush blueberries. Fruit dry matter (DM) and titratable acidity (TA) were higher in the Xtend ${ }^{\circledR}$ package. Fruit SSC decreased in the LDPE packages and increased in the Xtend ${ }^{\oplus}$ packages during storage. Based on the decreased soluble solids content (SSC) and titratable acidity (TA) ratio (SSC:TA) values during storage, it can be concluded that the taste of the fruits became sourer in all packages. Anthocyanin biosynthesis of lowbush blueberries was suppressed in MA, but this effect was not noticed for 'Northblue'. Regarding fruit firmness, shrivelling, and decay, there were significant differences between the MA packages, but the genetic differences were more important: half-highbush blueberry fruits were firmer and less shrivelled.
\end{abstract}

Keywords: Vaccinium angustifolium; V. corymbosum $\times$ V. angustifolium; anthocyanins; soluble solids; titratable acidity; colour

\section{Introduction}

Interest in blueberries (Vaccinium spp.) is rising because of their health-promoting constituents, including flavonols, tannins, phenolic acids, and anthocyanins, which help to prevent cardiovascular diseases, cancer, and inflammation [1]. Internationally blueberries are sold in fresh, frozen, and processed forms, and additional research is needed to extend the postharvest life of fresh blueberries to further extend the marketing season and to reduce waste.

The postharvest quality of blueberries is affected by diverse physical, physiological, and pathological processes and aspects of blueberry deterioration including decay, shrivelling, and softening [2]. Major causes of postharvest spoilage for blueberries are fungal decay and physiological changes [3]. Though, storing blueberries in a $\mathrm{CO}_{2}$-enriched atmosphere is an effective way of extending the postharvest life and inhibiting postharvest decay without fungicidal treatments [4]. 
Modified-atmosphere packaging has the potential to provide low $\mathrm{O}_{2} /$ high $\mathrm{CO}_{2}$ regimes, but the packaging must maintain the appropriate atmospheric composition over a range of temperatures commonly encountered between harvest and consumption [5].

Modified atmosphere packages combined with an optimal storing temperature extend the storability of fresh produce by maintaining the sensory and nutritional quality [6,7]. Although several studies have found no significant differences in storing blueberries in the range of $0-5^{\circ} \mathrm{C}[2,8,9]$, the most popular storage temperature is close to $0{ }^{\circ} \mathrm{C}[10,11]$. At these temperatures, the blueberry may be stored in a regular atmospheric storage for a maximum of 2 weeks. By raising the humidity to $85-89 \%$, the postharvest life can be extended for up to 6 weeks [12,13].

In Estonia, blueberries are sold mostly as fresh market fruit. Since a truly temperate climate is prevalent for the region [14], winter hardiness is the most important requirement for cultivar selection. Previous studies have suggested lowbush ( $V$. angustifolium Ait.) and half-highbush blueberries (V. corymbosum $\times$ V. angustifolium) ('Northblue') as being suitable for cultivating under these climatic conditions [15-17].

A large volume of postharvest work has been performed with highbush blueberry cultivars (Vaccinium corymbosum L.), with particular reference to controlled atmosphere storage [5]. However, the current novel study was initiated as information concerning the modified atmosphere storage of lowbush and half-highbush blueberries is not well known. Furthermore, there are very few postharvest studies concerning organically grown blueberries.

Our hypothesis was that postharvest life of lowbush blueberries and half-highbush blueberries may be extended using modified atmosphere packaging without affecting the fruit quality. The aim of the study was to determine the effect of modified atmosphere (MA) packages on organically grown lowbush blueberry and half-highbush blueberry ('Northblue') external quality and the nutritional value of the fruits.

\section{Materials and Methods}

\subsection{Plant Material and Storage Conditions}

Two species of blueberry were investigated: the lowbush blueberry (Vaccinium angustifolium Ait.) and the half-highbush blueberry (Vaccinium corymbosum $\times$ V. angustifolium) cultivar 'Northblue'. The fruits were collected from a commercial farm in the Tartu county, South Estonia (58 $\left.12^{\prime} \mathrm{N}, 26^{\circ} 41^{\prime} \mathrm{E}\right)$. Bushes were grown organically in the soil subgroup Fibri-Dystric Histosol [18] with a residual peat layer that was 1.0-1.5 m deep. Uniform, disease-free blueberries at commercial maturity (beginning of August) were hand-picked into regular-atmosphere 250-g perforated polyethylene terephthalate "plastic" punnets (Infia TR80/58 mm, Produce Packaging, HL Hutchinson Ltd., Cambridgeshire, UK). Punnets were designed for soft and highly perishable fruits such as cherries and tomatoes [19]. Mass of the perforated punnets was $8 \mathrm{~g}$ and the dimensions were $143 \times 96 \times 58 \mathrm{~mm}$. Punnets had four circular perforations (diameter $8 \mathrm{~mm}$ ) at the bottom and the lid had eight oval perforations $(20 \times 5 \mathrm{~mm})$. Treatments included:

1. a control, consisting of four regular atmospheric storage (RA) punnets only;

2. four regular atmosphere punnets sealed in a $30 \mu \mathrm{m}$ thick low-density polyethylene (LDPE) modified atmosphere bag (product of Estiko, Estonia);

3. four regular atmosphere punnets sealed in an $X$ tend ${ }^{\circledR}$ modified atmosphere blueberry bag (Stepac, Israel).

There were 6 replicates per treatment and all treatments, including the control, were stored at $3 \pm 1{ }^{\circ} \mathrm{C}$ for six weeks. Relative humidity ranged from 96 to $98 \%$. The fruits were analysed on the day of harvest and then 1 replication of four boxes of blueberries was destructively sampled each week. Postharvest shelf-life was considered terminated when either the berries were too soft (firmness below 6.0 points), when shrivelling was $\geq 10 \%$, or when the decay was $\geq 5 \%$. For each treatment shelf-life was 
considered terminated at a different time: in regular atmosphere punnets it was 22 days for lowbush blueberry and 28 days for half-highbush 'Northblue'; in LDPE modified packaging, it was 22 days for lowbush and 37 days for the half-highbush blueberry 'Northblue'. For Xtend ${ }^{\circledR}$ modified atmospheric packaging it was 37 days for both species. In this manuscript, the results at harvest (in the tables named Pre-storage) and at the end (in the tables named After storage) of each treatment are presented.

\subsection{Gas Measurements}

During storage, $\mathrm{O}_{2}$ and $\mathrm{CO}_{2}$ concentrations were measured using a hand-held gas analyser OXYBABY V (WITT-Gasetechnik GmbH \& Co. KG, Witten, Germany). $\mathrm{O}_{2}$ and $\mathrm{CO}_{2}$ concentrations (\%) were measured nine times from within each closed system. The integrity of each bagged system was maintained as an impermeable rubber septum was placed on the outside of each modified atmospheric bag and, through the septum, a gas analyser needle was inserted, and an aliquot of air was drawn out for both $\mathrm{O}_{2}$ and $\mathrm{CO}_{2}$ concentrations. $\mathrm{O}_{2}$ and $\mathrm{CO}_{2}$ concentrations in the natural atmosphere were measured above the berries from the headspace immediately above the perforated holes in the punnets.

\subsection{Subjective Quality Measurements}

Fruit firmness, shrivelling, and decay were determined after storage at $3{ }^{\circ} \mathrm{C}$. Firmness was evaluated on a sub-sample of 10 berries by hand rolling, using a $1-9$ scale $(1=$ berry ruptures on touch, $4.5=$ berry surface depressed on touch, $9=$ berry is firm, not yielding to touch). Shrivelling of the fruits was determined visually and was expressed as a percentage of all fruits in a punnet. Fruit decay was visually evaluated and it was expressed as a percentage of all fruits in a punnet. Any berries with visible mould growth were considered decayed. Pathogens were not identified in the experiment.

A trained sensory panel of 10 assessors was used for the sensory descriptive analysis. Prior to the sensory evaluation, assessors attended a discussion and training session, in which they were introduced to the experiment-specific criteria for sensory analyses. Evaluation criteria were conducted with modifications per the Schotsmans et al. [20] study.

\subsection{Fruit Quality Analyses}

Fruit quality characteristics were determined for each of the four punnets per replicate. All diseased berries were counted and removed. For chemical analyses, $100 \mathrm{~g}$ of the remaining healthy berries from each replication were pureed using a hand-held blender (Turbo MR 5550 M FP, Braun $\mathrm{GmbH}$, Barcelona, Spain). Measurements were repeated four times. Dry matter (DM) was determined using a $10 \pm 1 \mathrm{~g}$ sample and drying in a thermostat (Modell 400, Memmert GmbH + Co. KG Co., Schwabach, Germany) at $105{ }^{\circ} \mathrm{C}$ to a constant weight. Fruit dry matter content (\%) was calculated on a dry weight and fresh weight basis.

Soluble solids content (SSC) was analysed using a digital Pocket Pal-1 refractometer (Atago Co., Ltd., Tokyo, Japan). The instrument was calibrated with distilled water and the lens was carefully rinsed and wiped dry between samples. Results are expressed as \% of the fresh weight (FW) basis.

Titratable acidity (TA) was measured by neutralizing (to $\mathrm{pH}$ 8.2) $0.1 \mathrm{M}$ of $\mathrm{NaOH}$ solution (automatic titrator, Mettler Toledo DL 50 Randolino). Titratable acidity was expressed as \% of citric acid (\% FW), as citric acid was the dominant organic acid in blueberries, using the milliequivalent factor of 0.064 for the citric acid. From these data, the SSC:TA ratio was calculated.

For the determination of anthocyanins (ACY), 50 whole fruits were crushed, and $10 \mathrm{~g}$ of the crushed fruit was soaked in an extracting solution containing $\mathrm{HCl}(0.1 \mathrm{M}): \mathrm{C}_{2} \mathrm{H}_{5} \mathrm{OH}(96 \%)=15: 85$ (v/v). Solutions were shaken and held at $5{ }^{\circ} \mathrm{C}$ for $24 \mathrm{~h}$. Total anthocyanin content was determined spectrophotometrically using a Thermo Spectronic Hel $\lambda$ ios $\beta$ spectrophotometer (Thermo Scientific Inc., Loughborough, UK) by determining the difference in the absorbance between solutions of $\mathrm{pH} 1.0$ and $\mathrm{pH} 4.5$ at emissions of 510 and $700 \mathrm{~nm}$ [21]. Values are expressed as mg cyanidin-3-glucoside equivalents per $100 \mathrm{~g}$ FW using a molar extinction coefficient of $26,900 \mathrm{~L} \mathrm{~mol}^{-1} \mathrm{~cm}^{-1}$. 


\subsection{Colour Measurements}

Both the external (fruit surface/exocarp) and internal (flesh/mesocarp) colour were recorded using a reflectance colourimeter (Model CR-400, Minolta Co., Ltd., Tokyo, Japan). Two readings per fruit were taken on opposite sides of each of the 10 fruits from each replicate (from four punnets). In order to measure the colour of the fruit surface, the natural wax coating was removed mechanically (the method by Kalt et al. [22]), and the same fruits were measured with a wax and without a wax coating. For fruit flesh colour measurements, each fruit was bisected and measurements were taken immediately to avoid discolouration. The colour of the fruit was expressed as $\mathrm{L}^{*}$ (lightness; black $=0$, white $=100), \mathrm{a}^{*}$ (redness, red $=+60$, green $\left.=-60\right), \mathrm{b}^{*}$ (yellowness, yellow $=+60$, blue $\left.=-60\right), \mathrm{C}^{*}$ (chroma), and $\mathrm{h}^{*}$ (hue angle). A white plate was used for calibration (Illuminants $\mathrm{C}$ : $\mathrm{Y}=92.6 \mathrm{x}=0.3134$ $\mathrm{y}=0.3196$; illuminants D65: $\mathrm{Y}=92.6 \mathrm{x}=0.3160 \mathrm{y}=0.3324$ ).

\subsection{Statistical Analysis}

Statistical evaluation of the experimental results was performed by one-way analysis of variance (ANOVA, Fisher LSD Test). In figures and tables, all data are presented as means of the replications. Different letters indicate significant differences at $p<0.05$, similar letters do not indicate significant differences $(p>0.05)$. Data of $\mathrm{O}_{2}$ and $\mathrm{CO}_{2}$ from two blueberry species that were measured from different modified atmosphere packages (LDPE film and Xtend ${ }^{\circledR}$ film) were statistically analysed at the end of the storage period. Depending on the storage conditions (RA, LDPE and Xtend ${ }^{\circledR}$ film) firmness, shrivelling, and decay were compared at the end of the storage period as well. Dry matter, total anthocyanins, titratable acids, total soluble solids, SSC:TA, and the colour parameters $\left(\mathrm{L}^{*} \mathrm{a}^{*} \mathrm{~b}^{*}, \mathrm{C}^{*}\right.$ and $\mathrm{h}^{*}$ ) were statistically compared in pre-storage and after storage depending on the storage conditions (RA, LDPE, Xtend ${ }^{\circledR}$ film).

\section{Results and Discussion}

\subsection{Storage Time}

Regular atmospheric (RA) storage punnets at $3 \pm 1{ }^{\circ} \mathrm{C}$ and a relative humidity over $90 \%$ resulted in a postharvest life of 22 days for lowbush blueberries and up to 28 days for 'Northblue', but no longer (Figure 1). There was a significant improvement when the RA punnets were kept in modified atmosphere packages. Indeed, both the LDPE and Xtend ${ }^{\circledR}$ packages had a positive effect on the postharvest life for 'Northblue' for up to 37 days. However, for the lowbush blueberry LDPE, the packaging extended the postharvest life for only 22 days, which was similar to the regular atmosphere storage in punnets, whereas the $X$ tend ${ }^{\circledR}$ packaging resulted in a shelf-life of up to 37 days. The postharvest shelf-life of blueberries is strongly correlated with genetics [23]. In our study, the half-highbush blueberry ('Northblue') had a longer postharvest life compared to the lowbush blueberry in the LDPE film, which refers to the genetic difference of these two taxa and may suggest that the suitability of the film is species-specific. Peano et al. [24] described that increasing the quantities of $\mathrm{CO}_{2}$ within the high-density polyethylene pallet and decreasing the quantities of $\mathrm{O}_{2}$ so as to reach values in a range of $10-12 \%$ for both gases made it possible to induce a slowdown of the respiratory metabolism of the fruits, which increased the conservation period up to 45 days. In the mentioned study, the blueberries were kept for another 15 days under in RA conditions, achieving an overall period of conservation of 60 days. 


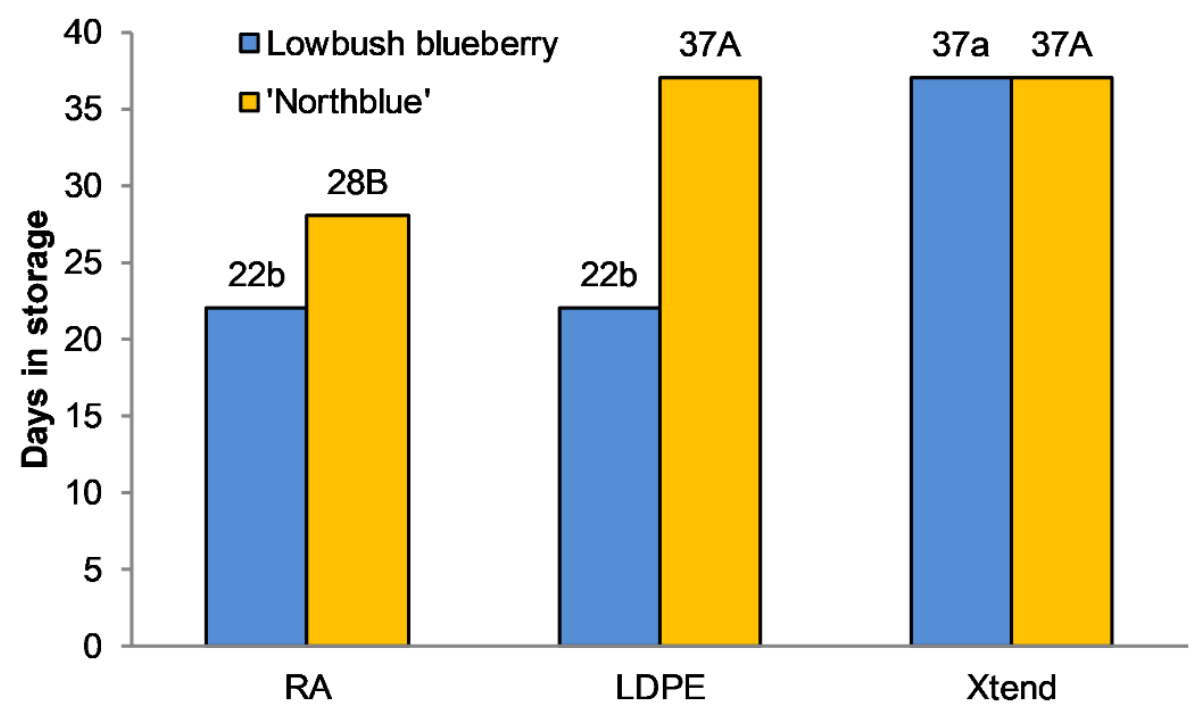

Figure 1. The postharvest life of the lowbush blueberry and half-highbush blueberry cultivar 'Northblue' at $3 \pm 1^{\circ} \mathrm{C}$ in regular atmosphere (RA) or modified atmosphere packages (LDPE film and Xtend ${ }^{\circledR}$ film). The means with different letters are significantly different $(p<0.05)$ : $a, b, c$ for lowbush blueberry and A, B, C for 'Northblue'. LDPE (30 $\mu \mathrm{m}$ low-density polyethylene bag, product of Estiko, Estonia. Xtend ${ }^{\circledR}$ blueberry bag, product of Stepac, Israel).

\section{2. $\mathrm{O}_{2}$ and $\mathrm{CO}_{2}$ Changes during Storage}

The modified atmosphere packaging consists of sealing a certain quantity of fruit or vegetables using plastic films; then the respiration of commodities increases the $\mathrm{CO}_{2}$ concentration and decreases the $\mathrm{O}_{2}$ concentration inside the packages, while the transpiration rate increases the vapour pressure [25]. Even different cultivars of the same species can exhibit different respiration rates $[13,23,26]$.

This trend was also observed in our study, although the $\mathrm{O}_{2}$ and $\mathrm{CO}_{2}$ concentrations did not reach the recommended levels suggested by Kader [27] and Mattos et al. [13]. They suggested that the optimal storage conditions of blueberries ranged from $0-5{ }^{\circ} \mathrm{C}$ with $\mathrm{O}_{2}$ concentrations between $2-5 \%$ and $\mathrm{CO}_{2}$ concentrations between $12-20 \%$. In our trial, the lowest $\mathrm{O}_{2}$ concentration recorded was $13 \%$ and the maximum $\mathrm{CO}_{2}$ concentration was ca. 9.3\%. The $\mathrm{O}_{2}$ concentration in the modified atmosphere packages did not have a significant difference: the $\mathrm{O}_{2}$ concentration dropped by $15.7 \%$ in the LDPE film bag and to $13.9 \%$ in the $\mathrm{Xtend}^{\circledR}$ bag for lowbush blueberries (Figure 2). For the half-highbush blueberry, the $\mathrm{O}_{2}$ concentration at the end of the trial decreased to $14.0 \%$ in the LDPE film bag and to $13.0 \%$ in the $\mathrm{Xtend}^{\circledR}$ film bag.

In contrast, the $\mathrm{CO}_{2}$ concentrations showed significantly different results compared to the $\mathrm{O}_{2}$, where $\mathrm{CO}_{2}$ increased to $3.4 \%$ in the LDPE film and to $8.5 \%$ in the $\mathrm{Xtend}^{\circledR}$ for lowbush blueberries (Figure 3). The difference between $\mathrm{CO}_{2}$ concentrations for lowbush blueberries may have been caused by the shorter storing time in the LDPE package. However, the same phenomenon was noticed with 'Northblue', where the $\mathrm{CO}_{2}$ content in the LDPE film was significantly lower $(4.8 \%)$ compared to Xtend ${ }^{\circledR}(9.4 \%)$. In the previous modified atmosphere study with raspberries, the $\mathrm{O}_{2}$ concentration was also somewhat higher in the $X$ tend $^{\circledR}$ film compared to LDPE: 15.7 and $14.9 \%$, respectively [28]. 


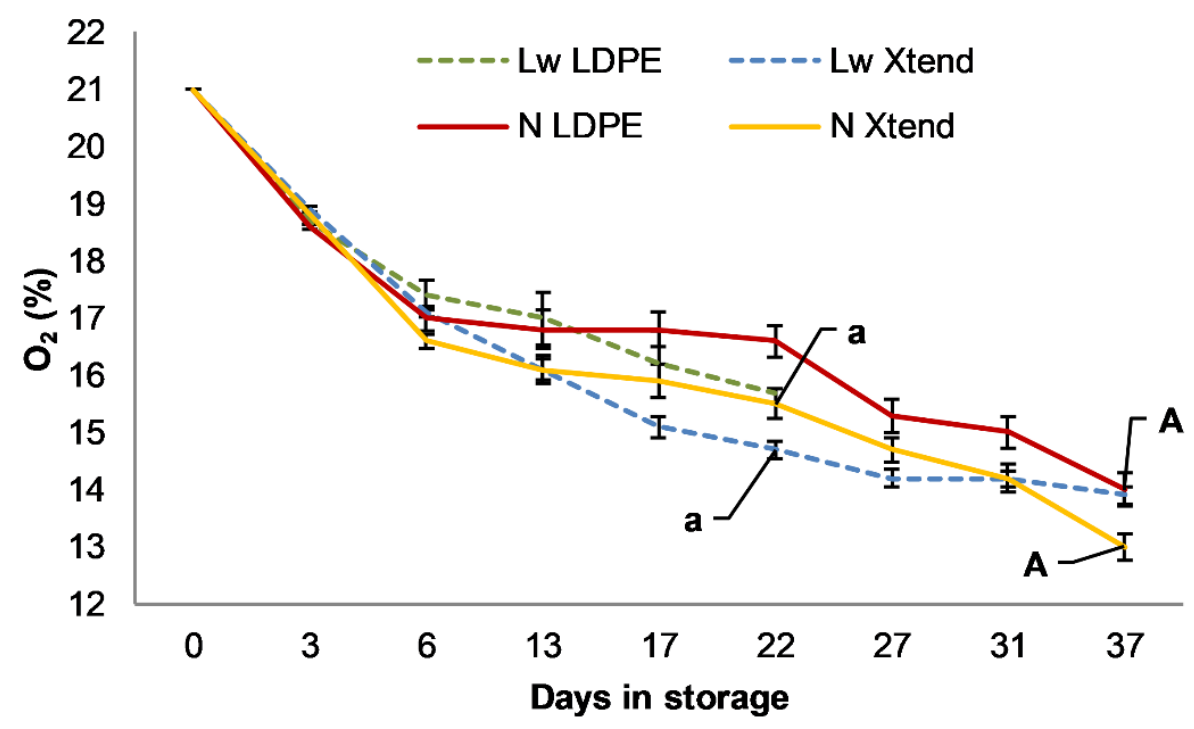

Figure 2. The changes in the $\mathrm{O}_{2}$ concentration in the modified atmosphere packages (LDPE film and Xtend ${ }^{\circledR}$ film) of the lowbush blueberry and half-highbush blueberry cultivar 'Northblue' during storage at $3 \pm 1{ }^{\circ} \mathrm{C}$. (LW: lowbush blueberry. N: half-highbush blueberry ('Northblue')). Means for each parameter followed by a different letter are significantly different $(p<0.05)$ : a, b, c for lowbush blueberries and A, B, C for 'Northblue'. LDPE (30 $\mu \mathrm{m}$ low-density polyethylene bag, product of Estiko, Estonia. Error bars indicate the standard error. Xtend ${ }^{\circledR}$ blueberry bag, product of Stepac, Israel.)

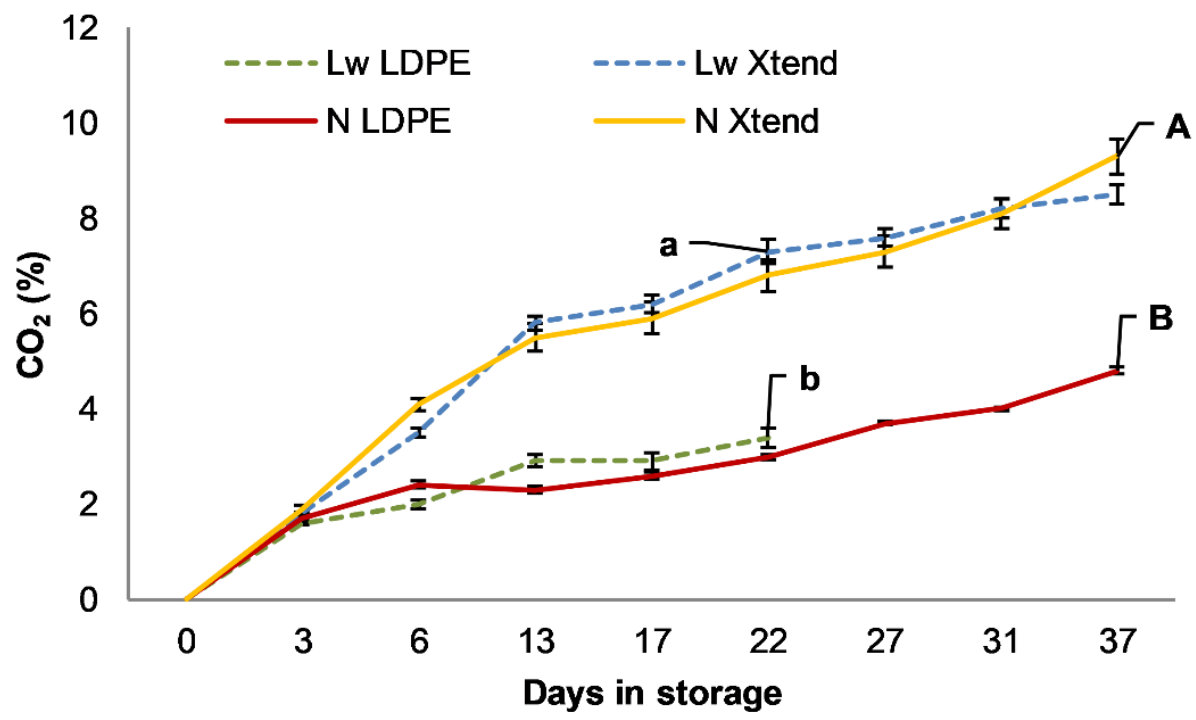

Figure 3. The changes in the $\mathrm{CO}_{2}$ concentration (\%) in the modified atmosphere packages (LDPE film and Xtend ${ }^{\circledR}$ film) of lowbush blueberry and half-highbush blueberry cultivar 'Northblue' during storage at $3 \pm 1^{\circ} \mathrm{C}$. (LW: lowbush blueberry. $\mathrm{N}$ : half-highbush blueberry ('Northblue')). The means for each parameter followed by a different letter are significantly different $(p<0.05)$ : a, b, c for lowbush blueberry and A, B, C for 'Northblue'. Error bars indicate the standard error. LDPE (30 $\mu \mathrm{m}$ low-density polyethylene bag, product of Estiko, Estonia. Xtend ${ }^{\circledR}$ blueberry bag, product of Stepac, Israel).

At the end of the raspberry experiment, the $\mathrm{O}_{2}$ content reached 15.1\% in the LDPE and 13.1\% in the Xtend ${ }^{\circledR}$ bags. In that study, the $\mathrm{CO}_{2}$ content increased to $5.1 \%$ in the LDPE film and to $6.1 \%$ in the $X$ tend $^{\circledR}$ bags during the first $24 \mathrm{~h}$, at the end of the experiment, it became 5.9\% in the LDPE and to $7.3 \%$ in the $X$ tend ${ }^{\circledR}$. In another previous modified atmosphere experiment with strawberries, the $\mathrm{O}_{2}$ decrease and the $\mathrm{CO}_{2}$ increase was more rapid in the LDPE packages compared to the Xtend ${ }^{\circledR}$ packages, which suggests that that LDPE bags are less permeable to respiration gases [29]. Our experiment showed similar trends, where the LDPE bag's $\mathrm{CO}_{2}$ concentration did not reach the desired 
levels, which may have resulted in a poorer storability for the lowbush blueberry. Beaudry et al. [5] observed that the atmospheric partial pressures of $\mathrm{O}_{2}$ within the low-density polyethylene packages containing same mass of blueberries decreased with the increasing temperature and vice versa, which indicates that the activation energy of the film $\mathrm{O}_{2}$ permeation was less than the activation energy of the fruit. Previous studies have also reported that the steady-state $\mathrm{O}_{2}$ and $\mathrm{CO}_{2}$ levels depend on film permeability and the product respiration rate and that the temperature dependence is determined by the film type and commodity physiology $[5,23]$. Different varieties of the same product exhibit specific respiration rates [13] and the success of the modified atmosphere packaging greatly depend on the accuracy of the predictive respiration rate [27]. The MAP storage with the starch films by Giuggioli et al. [30] helped to control the changes in post-harvest physicochemical properties, such as the $\mathrm{pH}$ and TA, but also maintained the antioxidant and nutritional values of fruits after 15 days of storage. In another experiment with three highbush blueberry cultivars 'Coville', 'Blueray', and 'Jersey', the fruit respiration rates in the modified atmosphere decreased with the increasing $\mathrm{CO}_{2}$, but were little affected by changes in $\mathrm{O}_{2}$ [23]. On the contrary, Beaudry et al. [5] suggested that the respiration is minimally affected by levels of $\mathrm{CO}_{2}$ below the approximate $20 \mathrm{kPa}$ that accumulated in the packages under hypoxic conditions. In their work with highbush cultivar 'Bluecrop', the oxygen consumption decreased in response to the decreasing temperature and decreasing steady-state $\mathrm{O}_{2}$, where the shape of the $\mathrm{O}_{2}$-dependent respiratory curves changed with temperature. The phenomenon was that, at the higher temperatures, the $\mathrm{O}_{2}$ uptake did not appear to approach saturation even at the highest levels of steady-state $\mathrm{O}_{2}$ generated and, as a result, the fruits were found to be more sensitive to restricted $\mathrm{O}_{2}$ availability as temperatures increased. Hall and Forsyth [31], on the other hand, indicated that the longer the fruits were left on the bushes, the lower their rate of respiration would be. In our experiment, berries from both taxa were picked at the same time and there were no differences in the berry ripening stages. During the trial, the $\mathrm{O}_{2}$ consumption and $\mathrm{CO}_{2}$ production were similar with both taxa at a temperature of $3 \pm 1{ }^{\circ} \mathrm{C}$ but they were influenced by the modified atmosphere packages. At the same time, the content of $\mathrm{CO}_{2}$ did not increase up to the critical level in any of the used modified atmosphere packages. For the half-highbush blueberry, the limits had not been worked out till now, but earlier studies have mentioned that for highbush and lowbush blueberries, the suitable $\mathrm{CO}_{2}$ content in storage ranges from $5 \%$ to $15 \%$ when kept at $5{ }^{\circ} \mathrm{C}$ or below $[5,12]$. Analogous parameters for $\mathrm{O}_{2}$ content are between 1 and $10 \%$. In our study, the oxygen content was higher in each package in case of both taxa during the experimental period. It can be concluded that the LDPE package is not suitable for lowbush blueberry because it did not extend the postharvest life and the gas concentration did not exceed to desired levels. Although $\mathrm{O}_{2}$ did not decrease and $\mathrm{CO}_{2}$ did not increase as expected, especially in LDPE package, the positive side was that the anaerobic respiration did not take place during storage in both packages.

\subsection{Fruit Firmness}

Early works have stated that blueberries undergo chemical and physical modification during storage [7], which includes fruit firmness, shrivelling, senescence, and the development of decay organisms.

In our study, the lowbush blueberry fruit in the Xtend ${ }^{\circledR}$ film stayed firmer compared to the regular atmosphere, scoring 6.0 and 5.0 points, respectively (Table 1). This result is an expected consequence, which allows us to suggest that the respiration rate is higher in the regular atmosphere and that an atmosphere has a major role in accelerating the moisture loss, although the loss of firmness may have been affected by the subsequent compression of the berries in the box during the storage. Prange et al. [32] showed that the firmness of the lowbush blueberry decreased over time, especially after 42 days (1.6-3.4 points in the 0-5-point scale). However, they suggested that an $\mathrm{O}_{2}$ concentration of $1-5 \%$ may also improve the firmness retention with a storage time $>28$ days. Paniagua et al. [2] reported that the storage atmosphere influenced the firmness of the blueberries, however, its effect varied among the cultivars and storage temperature. 
Table 1. The fruit firmness (points), shrivelling (\%), and decay (\%) of the lowbush blueberry and half-highbush blueberry cultivar 'Northblue' after storage at $3 \pm 1{ }^{\circ} \mathrm{C}$ in a regular atmosphere (RA) or modified atmosphere packages (LDPE film and $\mathrm{Xtend}^{\circledR}$ film).

\begin{tabular}{ccccccc}
\hline & \multicolumn{3}{c}{ Lowbush Blueberry } & \multicolumn{3}{c}{ 'Northblue' } \\
\hline & RA & LDPE & Xtend ${ }^{\circledR}$ & RA & LDPE & Xtend $^{\circledR}$ \\
Firmness (points) & $5.0 \mathrm{~b}$ & $5.3 \mathrm{ab}$ & $6.0 \mathrm{a}$ & $7.3 \mathrm{~A}$ & $7.0 \mathrm{~A}$ & $7.0 \mathrm{~A}$ \\
Shrivelling (\%) & $13.0 \mathrm{a}$ & $3.0 \mathrm{c}$ & $5.0 \mathrm{~b}$ & $0.1 \mathrm{~B}$ & $0.1 \mathrm{~B}$ & $2.0 \mathrm{~A}$ \\
Decay (\%) & $0.1 \mathrm{~b}$ & $0.4 \mathrm{a}$ & $0.1 \mathrm{~b}$ & $3.0 \mathrm{C}$ & $15.0 \mathrm{~A}$ & $7.0 \mathrm{~B}$ \\
\hline
\end{tabular}

Means for each parameter followed by the same letter within each row are significantly different $(p<0.05): \mathrm{a}, \mathrm{b}, \mathrm{c}$ for lowbush blueberry and A, B, C for 'Northblue'. LDPE (30 $\mu \mathrm{m}$ low-density polyethylene bag, product of Estiko, Estonia. Xtend ${ }^{\circledR}$ blueberry bag, product of Stepac, Israel).

For instance, the cultivar 'Brigitta' had firmer fruits in $\mathrm{CO}_{2}$ of $10 \%$ in both $2.5 \%$ or $20 \%$ of oxygen in comparison to air at $4{ }^{\circ} \mathrm{C}$. In our study, the $\mathrm{CO}_{2}$ content was higher in the Xtend ${ }^{\circledR}$ packages for both taxa, but only the lowbush blueberry stayed firmer in the Xtend ${ }^{\circledR}$ package ( 6.0 points) compared to the regular atmosphere ( 5.0 points). For the 'Northblue', there was no significant difference between the firmness of fruits stored in the modified atmosphere packages, nor with the regular atmosphere. Correspondingly, the firmness of the 'Northblue' fruit was slightly higher compared to the lowbush fruit, where the firmness was 7.3 for the regular atmosphere and 7.0 in both modified atmosphere packages. 'Northblue' had a longer postharvest life compared to the lowbush blueberry, which could also be correlated to a better firmness performance. As mentioned, the lowbush blueberry had a softer fruit compared to the half-highbush blueberry, which is a function of the genetic difference of these two taxa and agrees with earlier studies claiming that the firmness is determined on the genetics of the cultivar [2,8]. Ballington et al. [33] stated that when the blueberries are grown in a single location and year, the genetic factors are more important than the environmental differences within the field. Vicente et al. [34] claimed that the firmness/softening depends mainly on hemicellulosic depolymerization, however, Fava et al. [35] stated that the elasticity/turgidity is more related to the internal turgor pressure regulated largely by the cuticular wax properties, because wax is a very good barrier to the excessive water loss [36]. Based on this knowledge, the interaction between wax and the gradient was also observed in our study, where the half-highbush cultivar 'Northblue' with a high epidermal wax concentration, had less shrivelling, but the fruits were also firmer.

Anatomical differences between the blueberry cultivars could influence $\mathrm{CO}_{2}$ and $\mathrm{O}_{2}$ diffusion into the blueberry tissue, affecting the internal gas concentration and, hence, contributing to the genetic variability in response to the atmospheric change [2]. This trend was also observed in our trial, where the genetical variation had a significant influence on the firmness. The parental phenotype in the blueberry often determines progeny firmness characteristics [37]. The lowbush blueberry produces a soft-fruited progeny [38] and has also been shown to be less firm than a highbush blueberry [33]. The mentioned species are both ancestors of the half-highbush blueberry in our trial, thus, concerning the firmness, the half-highbush blueberry ('Northblue') performed similarly to the highbush blueberry. Ehlenfeldt and Martin [39] found that the half-highbush cultivar 'Polaris' produced berries as firm as the highbush cultivar 'Duke'. The other two half-highbush blueberry cultivars in the trial, 'St. Cloud' and 'Friendship', had lower firmness values. Consequently, we conclude that the half-highbush blueberry cultivars that possess significant amounts of $V$. angustifolium ancestry seem to show a propensity for producing softer fruit. Giongo et al. [40] claimed that after the harvest, berry turgidity becomes more important than firmness. In the aforementioned study, the hybrid 'Northblue' was placed in a group which was characterized by a low texture performance with a high elasticity and deformable structure, which may lead to the perception of gumminess by consumers. The storage index for the texture dynamics of 27 cultivars (both highbush and hybrid) was employed, where 'Northblue' ranked slightly below average. Although the half-highbush blueberry 'Northblue' did not have good postharvest properties in this particular study, we concluded that it has better texture dynamics than the lowbush cultivar in our trial. As reported, the half-highbush blueberry 'Northblue' 
performed better than the lowbush blueberry, having a firmness around 7.0-7.3 points, while the lowbush blueberry firmness range was within 5.0-6.0 points.

\subsection{Fruit Shrivelling}

Berries are very susceptible to water loss, which results in a loss of gloss, fruit shrivelling, and an increase of firmness [12]. Weight losses of 5\% lead to wilting and poor texture, and the taste is considered critical for blueberry marketability [41]. In our trial, the lowbush blueberry had a higher shrivelling percentage than the half-highbush blueberry 'Northblue', which can be correlated to a higher water loss of lowbush compared to the half-highbush 'Northblue' (Table 1).

There was a significant interaction between the modified atmosphere packages and fruit shrivelling (Table 1). The highest percentage of shrivelling for the lowbush blueberry was in the regular atmospheric storage (13.0\%) compared to Xtend ${ }^{\circledR}(5.0 \%)$ and to LDPE films (3.0\%). Contrastingly, the half-highbush blueberry had more shrivelled fruits in the Xtend ${ }^{\circledR}$ film bags (2.0) compared to the regular atmospheric storage $(0.1 \%)$ and LDPE film bag treatment $(0.1 \%)$.

High water loss from the fruit is correlated with the high transpiration intensity [13], which can lead to extensive shrivelling and loss in marketable berries. For both taxa, the $\mathrm{CO}_{2}$ content was higher in the Xtend ${ }^{\circledR}$ package compared to the LDPE package. Correspondingly, the fruits in the Xtend ${ }^{\circledR}$ film had a higher percentage of shrivelling, 5.0\% for lowbush blueberry and 2.0\% for 'Northblue'. When comparing the overall postharvest life performance, we conclude that the genetic factors are again more important than the $\mathrm{O}_{2}$ and $\mathrm{CO}_{2}$ content in the packages, although the packaging had significant effects, the half-highbush blueberry 'Northblue' had remarkably less shrivelled berries compared to the lowbush blueberry, and the half-highbush performed better with both modified atmosphere packages.

\subsection{Fruit Decay}

Postharvest diseases of blueberries are usually caused by fungi, with anthracnose (Colletotrichum acutatum) being the most common fungal disease, followed by alternaria rot (Alternaria spp.) and grey mould (Botrytis cinerea) [10,42]. In an experiment with highbush blueberry, Echeverría et al. [43] found that there were no differences in the postharvest behaviour between fruits from organic or from conventional fertilization. Larger pathogen damage occurred in the fruits from organic fertilization treatments and were more decayed. Previous studies claim that lowbush blueberries show little decay during the storage, which is defined as the presence of visible mould [11]. This trend was also noticed in our trial, where the lowbush blueberry had less decayed berries compared to the half-highbush blueberry 'Northblue' (Table 1). In the modified atmospheric storage, the berries continue to respire the trapped air until the $\mathrm{CO}_{2}$ concentration rapidly approached the critical 10-15\% level necessary to inhibit the Botrytis growth [12]. In our study, the $\mathrm{CO}_{2}$ concentration was much lower for the lowbush, peaking at only $3.4 \%$ in the LDPE film bag and $8.5 \%$ in the Xtend ${ }^{\circledR}$ package. For the half-highbush blueberry 'Northblue', the $\mathrm{CO}_{2}$ content in the LDPE was $4.8 \%$ and $9.4 \%$ in the $\mathrm{Xtend}^{\circledR}$ film. These results indicate that for the half-highbush blueberry 'Northblue', $\mathrm{CO}_{2}$ concentration in the modified atmospheric packaging must be much higher to inhibit fungal growth. Paniagua et al. [2] observed that after 6 weeks of storage, the low oxygen concentrations $\left(2.5 \% \mathrm{O}_{2}+10 \% \mathrm{CO}_{2}\right)$ significantly reduced the decay for the cultivar 'Maru' in comparison to the air storage and both the controlled atmospheres decreased the decay for 'Brigitta'. High $\mathrm{CO}_{2}$ concentrations suppress decay, weight loss, and softening [32]. This was also observed in our study, where the $\mathrm{CO}_{2}$ concentration was higher in the $\mathrm{Xtend}^{\circledR}$ film compared to the LDPE film and, correspondingly, there were less decayed berries. Prange et al. [32] noticed that when increasing $\mathrm{CO}_{2}$, the visible decay decreased for both highbush varieties 'Fundy' and 'Blomidon', and at $15 \% \mathrm{CO}_{2}$, it was virtually absent $(0.1 \%)$. In their study, the increase of unmarketable berries was more related to a loss of firmness than due to the visible decay level. A similar trend was observed in our trial with the lowbush blueberry, where the increase of the unmarketable berries was more related to a loss of shrivelling than due to visible decay. 
A low $\mathrm{O}_{2}$ concentration during the blueberry storage has very little effect on the decay organism activity or survival at levels above the fermentation threshold of most commodities [13], thus, low $\mathrm{O}_{2}$ and elevated $\mathrm{CO}_{2}$ concentrations can remarkably reduce the rates of ripening and senescence, primarily reducing the synthesis and perception of ethylene [44]. Zheng et al. [45] found out that the modification of storage atmospheres induces plant defensive responses and increase disease resistance in postharvest commodities. A negative plant response to the modified atmosphere packaging is seen when the respiration is reduced as $\mathrm{O}_{2}$ becomes limiting and the lower $\mathrm{O}_{2}$ limit is frequently considered to be the level of $\mathrm{O}_{2}$ that induces fermentation [13]. A high ethylene content can influence the quality characteristics of blueberries like firmness, shrivelling, and decay. In our study, the $\mathrm{O}_{2}$ level did not have significant differences between the taxa, nor between the modified atmosphere packages. As mentioned before, for the lowbush blueberry, there were less decayed berries compared to the half-highbush blueberry 'Northblue' (Table 1). For lowbush, there was only a $0.1 \%$ of decayed berries observed in the regular atmospheric storage and in the $X$ tend $^{\circledR}$ film, which is significantly less compared to the LDPE film (0.4\%). The percentage of decayed fruits for the half-highbush blueberry 'Northblue' was $15.0 \%$ in the LDPE film, 7.0\% in the Xtend ${ }^{\circledR}$ film, and 3.0\% in the regular atmospheric storage. The fungal growth of the half-highbush blueberry 'Northblue' could have been suppressed by lowering the storing temperature since the previous studies have demonstrated that storing them at $0{ }^{\circ} \mathrm{C}$ has the great benefit of maintaining the quality. In the study by Paniagua et al. [2], a higher temperature $\left(4^{\circ} \mathrm{C}\right.$ in comparison to $\left.0{ }^{\circ} \mathrm{C}\right)$ resulted in more rot incidence from 5 weeks onwards for 'Brigitta' and after 4 weeks onwards for 'Maru'. Earlier works have also suggested that minimal mechanical damage and storage at $0{ }^{\circ} \mathrm{C}$ gives the advantage of maintaining the quality of the highbush [10] and lowbush blueberries [11,46]. The reported enhanced temperature conditions during blueberry storage could also be beneficial for the half-highbush blueberry 'Northblue' storage since the decay percentage was high when the fruit was stored at $3 \pm 1{ }^{\circ} \mathrm{C}$.

\subsection{Chemical Composition}

Fruit sensory quality, which is based on the chemical composition of the fruit, is strongly influenced by the storing techniques. At the end of the experiment, fruit dry matter content in both blueberry taxa was significantly higher in fruits stored in Xtend ${ }^{\circledR}$ packages compared to the RA and LDPE packages lowbush blueberry (Table 2). It showed that water loss was higher in Xtend ${ }^{\circledR}$ packages. Kalt and McDonald [47] have described the chemical composition of several lowbush blueberries ('Blomidon', 'Cumberland', 'Fundy') and these cultivars had a higher average dry matter content $(15.4 \%)$ compared to the blueberries in our study (the average pre-storage dry matter content was $13.6 \%)$. A lower fruit dry matter content in our study may have been caused by the climate conditions, cultivation techniques, but may also be due to the genetic differences of the lowbush species.

The most important group of phenolics in blueberries is the flavonoids. The high antioxidant activity of fruits is attributed to anthocyanins. According to Chiabrando and Giacalone [6], the high antioxidant capacity of phenolic compounds has been maintained in blueberry fruits stored at $4{ }^{\circ} \mathrm{C}$. For the lowbush blueberry, the anthocyanin content was significantly higher in the regular atmosphere (151 mg $100 \mathrm{~g}^{-1}$ ) compared to the modified atmosphere packages (96 mg $100 \mathrm{~g}^{-1}$ in

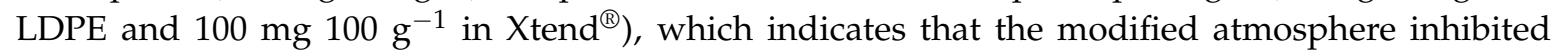
the anthocyanin biosynthesis. It could be suggested that the anthocyanin inhibition in LDPE is species-specific for lowbush blueberries, and may have been caused by the high shrivelling percentage. In the current study 'Northblue' had no significant difference between the anthocyanin content and the storage conditions and in contrast to the lowbush blueberry, neither of the packages influenced the anthocyanin biosynthesis. The same packaging materials as in our trial were used in modified atmosphere experiments with raspberry 'Polka' [28] and three different strawberry cultivars [29], where it was found that raspberries held in LDPE packages had significantly lower anthocyanin contents compared to the regular-atmosphere-stored fruits; however, for strawberries in LDPE packages, anthocyanin biosynthesis was inhibited only for 'Sonata', not in other cultivars. 
Table 2. The fruit dry matter (DM), anthocyanins (ACY), and soluble solids (SSC) content, titratable acidity (TA), soluble solids/titratable acidity ratio (TSS:TA) of lowbush blueberry and half-highbush blueberry cultivar 'Northblue' at harvest (Pre-storage) and after storage at $3 \pm 1{ }^{\circ} \mathrm{C}$ in regular atmosphere (RA) or modified atmosphere packages (LDPE film and $\mathrm{Xtend}^{\circledR}$ film).

\begin{tabular}{|c|c|c|c|c|c|c|c|c|}
\hline & \multicolumn{4}{|c|}{ Lowbush Blueberry } & \multicolumn{4}{|c|}{ 'Northblue' } \\
\hline & \multirow{2}{*}{ Pre-storage } & \multicolumn{3}{|c|}{ After storage } & \multirow{2}{*}{ Pre-storage } & \multicolumn{3}{|c|}{ After storage } \\
\hline & & RA & LDPE & Xtend ${ }^{\circledR}$ & & RA & LDPE & Xtend $^{\circledR}$ \\
\hline DM (\%) & $13.6 b$ & $13.6 b$ & $13.6 \mathrm{~b}$ & $15.1 \mathrm{a}$ & $13.1 \mathrm{~B}$ & $13.9 \mathrm{AB}$ & $13.2 \mathrm{~B}$ & $14.5 \mathrm{~A}$ \\
\hline ACY (mg/100 g) & $53 c$ & $151 a$ & $96 \mathrm{~b}$ & $110 \mathrm{~b}$ & $41 \mathrm{~B}$ & $103 \mathrm{~A}$ & $101 \mathrm{~A}$ & $103 \mathrm{~A}$ \\
\hline $\operatorname{SSC}(\%)$ & $13.1 b$ & $12.5 \mathrm{c}$ & $12.3 \mathrm{c}$ & $14.0 \mathrm{a}$ & $13.4 \mathrm{C}$ & $14.4 \mathrm{~A}$ & $12.4 \mathrm{D}$ & 13.9B \\
\hline TA $(\%)$ & $0.15 b$ & $0.14 b$ & $0.18 \mathrm{~b}$ & $0.27 \mathrm{a}$ & $0.66 \mathrm{D}$ & $0.73 C$ & $0.82 \mathrm{~B}$ & $0.89 \mathrm{~A}$ \\
\hline SSC:TA & $88 b$ & $94 a$ & $67 c$ & $52 d$ & $20 \mathrm{~A}$ & $20 \mathrm{~A}$ & $15 B$ & $16 \mathrm{~B}$ \\
\hline
\end{tabular}

Means for each parameter followed by the same letter within each row are significantly different $(p<0.05): \mathrm{a}, \mathrm{b}, \mathrm{c}$ $(p<0.05)$ for lowbush blueberry and A, B, C $(p<0.05)$ for 'Northblue'. LDPE $(30 \mu \mathrm{m}$ low-density polyethylene bag, product of Estiko, Estonia. Xtend ${ }^{\circledR}$ blueberry bag, product of Stepac, Israel).

The Xtend ${ }^{\circledR}$ package had a positive effect on the content of the soluble solids of both blueberry taxa: it was the only package which caused an increase of the soluble solids content during storage (Table 2). The LDPE film caused a significant decrease of the SSC in both blueberry taxa compared to the initial value, whereas the effect of the regular atmosphere storage depended on the blueberry taxa. The content of soluble solids of 'Northblue' fruits increased in the regular atmosphere and it resulted in significantly higher soluble solid contents compared to the fruits stored in either modified atmosphere packages after storage. Contrarily, the content of the soluble solids of the lowbush blueberry decreased in the regular atmosphere. Chiabrando and Giacalone [6] compared four different modified atmosphere packages with a highbush blueberry cultivar 'Lateblue' storage and found out that the microperforated ( $1 \mathrm{~mm} \varnothing)$ film and non-perforated film affected the total soluble solids content positively, having a total soluble solids content of $11.7 \%$ and $11.5 \%$, respectively.

The Xtend ${ }^{\circledR}$ package caused an increase in the titratable acids content in both blueberry taxa (Table 2), which may have been influenced by the dry matter content decrease during storage. Titratable acidity of 'Northblue' fruits increased in all packages (up by $0.73 \%$ in the regular atmosphere, $0.82 \%$ in LDPE, and $0.89 \%$ in $\mathrm{Xtend}^{\circledR}$, compared to the pre-storage $(0.66 \%)$ ). Lowbush blueberry titratable acidity remained unchanged in the regular atmosphere and LDPE packages during storage. On the contrary to our experiment, Zheng et al. [45] studied the impact of high oxygen $(40 \%, 60 \%, 80 \%$, and $100 \%)$ in modified atmospheres on highbush blueberry cultivar 'Duke' and reported significantly lower titratable acidity $(0.41-0.45 \%)$ within all the $\mathrm{O}_{2}$ types, but also with storage at $5{ }^{\circ} \mathrm{C}$ for 9,14 , or 35 days compared to the initial value $(0.82 \%)$. Chiabrando and Giacalone [6] reported that the highbush blueberry cultivar 'Lateblue' had the highest titratable acidity $\left(147.89 \mathrm{meq} \mathrm{L}^{-1}\right)$ with the microperforated $(1 \mathrm{~mm} \mathrm{Ø)} \mathrm{film,}$ compared to other modified atmosphere packages (38.89-59.58 meq L ${ }^{-1}$ ) and to the control (baskets without film): $60.25 \mathrm{meq} \mathrm{L}^{-1}$. These results indicate that the half-highbush blueberry 'Northblue' also has a high titratable acidity compared to the lowbush blueberry and is similar to the highbush cultivar 'Latebue'. Since 'Northblue' had significantly higher titratable acidity values compared to the lowbush blueberry, it indicates the genetic differences of these taxa, but also lets us conclude that the storage conditions had a smaller effect on the titratable acidity. Duan et al. [48] claimed that during postharvest storage, acid metabolism converted to starch and acid to sugar, thus, resulting in a decrease of the titratable acidity and an increase of soluble solids. However, in our study, this was not obvious, in fact, the titratable acids content increased in all storage conditions for 'Northblue' and in the Xtend ${ }^{\circledR}$ film for the lowbush blueberry. Gonçalves et al. [49] mentioned that the blueberries produced in organic farming had lower levels of titratable acids and the same situation continued after 7 and 14 days of storage.

The increase of the titratable acidity during regular and modified atmosphere storage might have also influenced the taste of the berries in our trial. Beaudry [50] reported in his study that blueberries 
should contain $>10 \%$ soluble solids, $0.3-1.3 \%$ titratable acidity, and have an SSC:TA ratio between 10 and 33 . A $0.1 \%$ decrease in the acid concentration is known to be equivalent to a $1 \%$ increase in the perceived sweetness in the blueberry fruit. In our study, the lowbush blueberry had a decrease of both soluble solids and an increase in the titratable acidity in the LDPE film (Table 2), which indicates, that the taste of fruits probably became more acidic. Changes in the taste are very well shown with the SSC:TA ratio, where the berry fruit in the LDPE film had a significantly lower SSC:TA ratio, 67, while the initial value was 88 . The lowbush blueberry fruits in the Xtend ${ }^{\circledR}$ package had an increase of both soluble solids and titratable acidity, resulting in the lowest SSC:TA ratio (among the package).

For 'Northblue', both the modified atmosphere packages caused a decrease in the SSC:TA ratio compared to the initial value. However, the differences in the SSC:TA between the regular atmosphere stored and modified atmosphere stored fruits were 4 to 5 units compared to the lowbush blueberries, where the difference between the regular atmosphere stored and the modified atmosphere stored fruits in the Xtend ${ }^{\circledR}$ package was 42 units (Table 2). Comparing these two taxa, the soluble solids and titratable acidity ratio had remarkable differences, where 'Northblue' had a more than four times lower SSC:TA ratio compared to the lowbush blueberry's initial value, which again indicates the genetic impact and its association to the flavour. The genetic impact is obvious, and the influence of the modified atmosphere package was also demonstrated. Thus, our results indicated that the taste-related properties of lowbush blueberries are more easily affected by the storage atmosphere than those of 'Northblue'.

\subsection{Fruit Colour Changes during Storage}

Blueberry colour is a complex quality characteristic affected by the quantity and structure of the surface waxes [51] and the anthocyanin content [52]. The colour of the fruit is also an important quality factor influencing fresh-market value and acceptability by the consumers [53-55].

The $L^{*}$ axis represents the lightness changes from 0 , which has no lightness (absolute black) to 100, which is the maximum lightness (absolute white) [56]. It is likely that the surface wax affects the $\mathrm{L}^{*}$ value (i.e., higher amounts of surface wax might lighten the fruit), as well as the visual perception of the fruit colour (e.g., blue chroma) [57]. However, in our study, this phenomenon was not apparent. The lowbush fruit surface with wax was lighter in colour before pre-storage $\left(L^{*} 29.3\right)$ compared to after storage in the regular atmosphere $\left(L^{*} 29.7\right)$ and in the LDPE film $\left(L^{*} 29.5\right)$ compared to the Xtend ${ }^{\circledR}$ ( $\mathrm{L}^{*}$ 25.6) (Table 3).

The 'Northblue' fruit surface with wax was lighter in colour in pre-storage $\left(\mathrm{L}^{*} 29.0\right)$ and in the LDPE film $\left(L^{*} 28.9\right)$ compared to the regular atmosphere $\left(L^{*} 26.0\right)$ and to the $X$ tend $^{\circledR}$ film $\left(L^{*} 27.0\right)$. Surface colour without wax was not different with respect to the $L^{*}$ values for both taxa. In the study with two highbush blueberry cultivars 'Bluetta' and 'Duke', where the blueberries were stored at room temperature or at $10{ }^{\circ} \mathrm{C}$, results were similar concerning the $L^{*}$ value [58]. In the mentioned study was no significant difference between both blueberry cultivars during the storage when the fruits were stored at $10^{\circ} \mathrm{C}$, where, at the end of the trial (at the 16th day), the $\mathrm{L}^{*}$ value for 'Bluetta' was 26.5 and for 'Duke' 25.9. It was interesting that the cultivar 'Duke' had an increase in $\mathrm{L}^{*}$ value, while 'Bluetta' had a slight decrease in lightness during storage. When comparing these results to our study, it can be suggested that the lowbush blueberry and half-highbush blueberry 'Northblue' have a higher $\mathrm{L}^{*}$ value compared to the highbush cultivars 'Bluetta' and 'Duke', which again reflect the genetic differences of these three taxa. In our study, the lowbush blueberry fruit flesh was lighter in colour with pre-storage ( $\left.L^{*} 39.1\right)$ and in the regular atmosphere $\left(L^{*} 41.3\right)$ compared to the fruit stored in the LDPE $\left(L^{*} 36.8\right)$ and in the Xtend ${ }^{\circledR}$ film ( $\left.\mathrm{L}^{*} 36.3\right)$. For 'Northblue', the fruit flesh was lighter in colour in the LDPE film ( $\left.L^{*} 55.7\right)$ compared to the initial value $\left(L^{*} 48.9\right)$ and to the regular atmosphere $\left(L^{*} 48.0\right)$, but there was no difference in the Xtend ${ }^{\circledR}$ film $\left(L^{*} 52.3\right)$. 
Table 3. The fruit surface (with wax and without wax) and flesh instrumental colour $\left(\mathrm{L}^{*} \mathrm{a}^{*} \mathrm{~b}^{*}, \mathrm{C}^{*}\right.$ and $\mathrm{h}^{*}$ ) of the lowbush blueberry and half-highbush blueberry cultivar 'Northblue' at harvest (Pre-storage) and after storage at $3 \pm 1^{\circ} \mathrm{C}$ in the regular atmosphere (RA) or modified atmosphere packages (LDPE film and $X$ tend $^{\circledR}$ film).

\begin{tabular}{|c|c|c|c|c|c|c|c|c|}
\hline \multirow{3}{*}{$\begin{array}{c}\text { Colour } \\
\text { Measurement }\end{array}$} & \multicolumn{4}{|c|}{ Lowbush Blueberry } & \multicolumn{4}{|c|}{ 'Northblue' } \\
\hline & \multirow{2}{*}{ Pre-storage } & \multicolumn{3}{|c|}{ After Storage } & \multirow{2}{*}{ Pre-storage } & \multicolumn{3}{|c|}{ After Storage } \\
\hline & & RA & LDPE & Xtend $^{\circledR}$ & & ${ }^{\text {e }}$ RA & LDPE & Xtend $^{\circledR}$ \\
\hline & \multicolumn{8}{|c|}{ Surface (with wax) colour } \\
\hline$L^{*}$ & $29.3 a$ & 29.7a & $29.5 a$ & $25.6 b$ & $29.0 \mathrm{~A}$ & $26.0 \mathrm{~B}$ & $28.9 \mathrm{~A}$ & $27.0 \mathrm{~B}$ \\
\hline$a^{*}$ & $1.07 \mathrm{~b}$ & $0.7 \mathrm{c}$ & $0.8 \mathrm{bc}$ & $2.0 \mathrm{a}$ & $0.4 \mathrm{C}$ & $1.0 \mathrm{~B}$ & $0.8 \mathrm{~B}$ & $1.5 \mathrm{~A}$ \\
\hline$b^{*}$ & $-5.6 b$ & $-6.3 b$ & $-6.0 \mathrm{~b}$ & $-4.4 \mathrm{a}$ & $-4.7 \mathrm{~B}$ & $-4.0 \mathrm{~A}$ & $-4.3 \mathrm{~A}$ & $-4.0 \mathrm{~A}$ \\
\hline$C^{*}$ & $5.7 \mathrm{ab}$ & $6.3 a$ & $6.1 \mathrm{ab}$ & $5.5 b$ & $4.7 \mathrm{~A}$ & $4.1 \mathrm{~B}$ & $4.4 \mathrm{AB}$ & $4.4 \mathrm{AB}$ \\
\hline \multirow[t]{2}{*}{$\mathrm{h}^{*}$} & $281 b$ & $277 \mathrm{~b}$ & $280 \mathrm{~b}$ & $297 \mathrm{a}$ & $275 B$ & $284 \mathrm{AB}$ & $282 \mathrm{AB}$ & $291 \mathrm{~A}$ \\
\hline & \multicolumn{8}{|c|}{ Surface (without wax) colour } \\
\hline$L^{*}$ & $23.5 \mathrm{a}$ & $22.9 \mathrm{a}$ & $22.7 \mathrm{a}$ & $23.4 \mathrm{a}$ & $24.1 \mathrm{~A}$ & $24.1 \mathrm{~A}$ & $24.0 \mathrm{~A}$ & $24.2 \mathrm{~A}$ \\
\hline$a^{*}$ & $1.1 \mathrm{a}$ & $0.9 a$ & $0.9 \mathrm{a}$ & $1.1 \mathrm{a}$ & $0.8 \mathrm{~B}$ & $1.3 \mathrm{~A}$ & $1.6 \mathrm{~A}$ & $1.6 \mathrm{~A}$ \\
\hline$b^{*}$ & $-0.8 b c$ & $-0.6 a$ & $-1.0 \mathrm{c}$ & $-1.9 \mathrm{~d}$ & $0.0 \mathrm{~A}$ & $-1.5 \mathrm{C}$ & $-1.0 \mathrm{~B}$ & $-0.9 \mathrm{~B}$ \\
\hline$C^{*}$ & $1.4 \mathrm{~b}$ & $1.2 \mathrm{~b}$ & $1.4 \mathrm{~b}$ & $2.3 \mathrm{a}$ & $0.8 \mathrm{~B}$ & $2.1 \mathrm{~A}$ & $2.0 \mathrm{~A}$ & $1.9 \mathrm{~A}$ \\
\hline \multirow[t]{2}{*}{$\mathrm{h}^{*}$} & $325 a$ & $327 a$ & $314 \mathrm{~b}$ & $306 \mathrm{~b}$ & $116 \mathrm{D}$ & $313 C$ & $324 \mathrm{~B}$ & $330 \mathrm{~A}$ \\
\hline & \multicolumn{8}{|c|}{ Flesh colour } \\
\hline$L^{*}$ & $39.1 \mathrm{a}$ & $41.3 \mathrm{a}$ & $36.8 b$ & $36.3 b$ & 48.9B & $48.0 \mathrm{~B}$ & 55.7A & $52.3 \mathrm{AB}$ \\
\hline$a^{*}$ & $2.4 \mathrm{c}$ & $4.3 \mathrm{~b}$ & $5.3 a$ & $5.8 \mathrm{a}$ & $-2.9 \mathrm{C}$ & $-0.9 \mathrm{~A}$ & $-2.9 \mathrm{C}$ & $-2.3 \mathrm{~B}$ \\
\hline$b^{*}$ & $3.6 a$ & $3.9 a$ & $2.9 \mathrm{~b}$ & $2.8 \mathrm{~b}$ & $9.3 \mathrm{C}$ & $8.8 \mathrm{C}$ & $11.2 \mathrm{~B}$ & $13.3 \mathrm{~A}$ \\
\hline$C^{*}$ & $5.0 \mathrm{c}$ & $6.1 \mathrm{~b}$ & $6.5 \mathrm{~b}$ & $7.4 a$ & $9.8 \mathrm{C}$ & $8.9 \mathrm{C}$ & 11.7B & $13.5 \mathrm{~A}$ \\
\hline$h^{*}$ & $90 \mathrm{~b}$ & $44 d$ & $68 c$ & $200 a$ & $105 \mathrm{~A}$ & $94 \mathrm{~B}$ & $103 \mathrm{~A}$ & 99AB \\
\hline
\end{tabular}

Means for each parameter followed by the same letter within each row are significantly different $(p<0.05): \mathrm{a}, \mathrm{b}, \mathrm{c}$ for lowbush blueberry and A, B, C for 'Northblue'. LDPE (30 $\mu \mathrm{m}$ low-density polyethylene bag, product of Estiko, Estonia. Xtend ${ }^{\circledR}$ blueberry bag, product of Stepac, Israel).

For both taxa, the lowbush and half-highbush blueberry, the fruit surface with wax had a higher degree in redness in the Xtend ${ }^{\circledR}$ film compared to the pre-storage and the LDPE film (Table 3). The lowest degree in redness was in the regular atmosphere $\left(a^{*} 0.7\right)$ for the lowbush blueberry. For 'Northblue', the lowest degree in redness was in the pre-storage $\left(a^{*} 0.4\right)$ compared to the Xtend ${ }^{\circledR}$ package. Fruit surface colour without the wax was not different between the treatments in the lowbush trial, but for the 'Northblue' there was, where the initial value $\left(a^{*} 0.8\right)$ was different for all the storage types, which also indicates that the fruits became redder during storage. The lowbush blueberry's fruit flesh had the highest degree in redness in the LDPE $\left(a^{*} 5.3\right)$ and in the Xtend ${ }^{\circledR}$ films $\left(a^{*} 5.8\right)$ compared to the initial value $\left(a^{*} 2.4\right)$. The flesh colour was remarkably different between the lowbush and the hybrid, where 'the Northblue' fruits were greener in colour, especially before storage $\left(a^{*}-2.9\right)$ and in the LDPE film $\left(a^{*}-2.9\right)$ compared to the fruits in the regular atmosphere $\left(a^{*}-0.9\right)$ and in the Xtend ${ }^{\circledR}$ film $\left(a^{*}-2.3\right)$.

The lowbush blueberry fruit surface colour with wax was bluer in colour in the pre-storage $\left(b^{*}-5.6\right)$, in the regular atmosphere $\left(b^{*}-6.3\right)$, and in the LDPE film $\left(b^{*}-6.0\right)$ (Table 3) compared to the Xtend ${ }^{\circledR}$ film $\left(b^{*}-4.4\right)$. For 'Northblue', the fruit surface colour with wax was bluer in colour with the pre-storage $\left(b^{*}-4.7\right)$ compared to all other storage types. Lowbush fruit without wax was bluer in colour in the Xtend ${ }^{\circledR}$ film $\left(b^{*}-1.9\right)$ compared to the pre-storage and other storage types. For 'Northblue', the fruit colour without the wax was bluer in the regular atmosphere $\left(b^{*}-1.5\right)$ compared to the initial value $\left(b^{*} 0.0\right)$. The fruit flesh had the highest degree of yellowness in the pre-storage $\left(b^{*} 3.6\right)$ and in the regular atmosphere $\left(b^{*} 3.9\right)$ conditions for the lowbush blueberry. For 'Northblue', the fruit was more yellow in colour in the $X$ tend ${ }^{\circledR}$ package $\left(b^{*} 13.3\right)$ compared to the pre-storage $\left(b^{*} 9.3\right)$, to the regular atmosphere $\left(b^{*} 8.8\right)$, and to the LDPE ( $\left.b^{*} 11.2\right)$ (Table 3$)$. There was a pronounced effect of the taxa concerning fruit flesh $b^{*}$ values, where 'Northblue' had significantly higher $b^{*}$ values in a ratio of 8.8-13.3, when compared to the lowbush, which had $b^{*}$ values in a ratio between 2.8-3.9. 
The lowbush blueberry's flesh colour was higher in RA ( $\left.b^{*} 3.9\right)$ compared to LDPE $\left(b^{*} 2.9\right)$ and to Xtend ${ }^{\circledR}\left(b^{*} 2.8\right)$, which may be due to the high shrivelling percentage that also had an impact on the anthocyanin inhibition during storage.

The chroma value was affected by the storage conditions, indicating that the tonality of the fruit colour changed after the harvest and was differentiated significantly $(p>0.05)$ (Table 3$)$. The packaging material did not affect the $C^{*}$ values of the exocarp and mesocarp. The lowbush fruit colour with wax had the highest $C^{*}$ value in the regular atmosphere $\left(C^{*} 6.3\right)$ compared to the $X$ tend ${ }^{\circledR}$ film $\left(C^{*} 5.5\right)$. For the half-highbush blueberry 'Northblue', the $C^{*}$ was highest in the pre-storage $\left(C^{*} 4.7\right)$ compared to the regular atmosphere $\left(C^{*} 4.1\right)$. The $X$ tend $^{\circledR}$ had a significant effect on the chroma when the chroma measurements were taken without the wax from the mesocarp. Chroma values for lowbush were higher in the $X$ tend ${ }^{\circledR}$ film $\left(C^{*} 2.3\right)$ when compared to the pre-storage $\left(C^{*} 1.4\right)$ and to the other storage types (for example, $C^{*} 1.2$ in a regular atmosphere and $C^{*} 1.4$ in the LDPE film). For 'Northblue', the surface colour without wax was higher in chroma values in all the other storage conditions when compared to the pre-storage. There were also higher $C^{*}$ values in the mesocarp compared to the exocarp of the half-highbush blueberry 'Northblue' fruit. Chroma measured from fruit flesh was higher in the $\mathrm{X}$ tend ${ }^{\circledR}$ film for both taxa compared to all other storage types.

Hue angle is a good measure of blueberry colour and the blue colour of the fruits has been suggested as the best criteria of fruit maturity and decision-making regarding harvesting time [58,59]. The higher hue angle values indicate bluer colours. For the lowbush blueberry, the $h^{*}$ from the fruit with wax was higher in the $X \operatorname{tend}^{\circledR}$ package $\left(h^{*} 297\right)$ compared to the pre-storage $\left(h^{*} 281\right)$, to the regular atmosphere $\left(h^{*} 277\right)$, and to the LDPE bag $\left(h^{*} 280\right)$ (Table 3). For 'Northblue', the hue angle increased in the Xtend ${ }^{\circledR}$ film $\left(h^{*} 291\right)$ compared to the initial value $\left(h^{*} 275\right)$. In the Eum et al. study [58], the hue angle was similar for highbush cultivars 'Bluetta' and 'Duke', when compared to the $h^{*}$ values we got in our study. The highbush blueberry cultivar 'Bluetta' had an $\mathrm{h}^{*}$ angle of 289.6 at $10^{\circ} \mathrm{C}$, while 'Duke' had a hue angle of 298.1. Although there was a significant difference between the two highbush cultivars at the beginning of the trial, these two cultivars had similar values during the rest of the storage. Compared to our study, the highbush blueberry cultivars had similar $\mathrm{h}^{*}$ values to the lowbush blueberry and half-highbush blueberry 'Northblue', when the hue angle was measured from the surface with wax, which indicates that these taxa have similar blue colours. The $h^{*}$ value, which was measured from the fruit without wax, was higher both in the pre-storage $\left(h^{*} 325\right)$ and in the regular atmosphere $\left(h^{*} 327\right)$ compared to the modified atmosphere packages, where, in the LDPE, it was 314 and in the $X$ tend $^{\circledR}$, it was 306 . For half-highbush, the $\mathrm{h}^{*}$ values without wax were approximately three times higher in the $X \operatorname{tend}^{\circledR}\left(h^{*} 330\right)$ compared to the initial value $\left(h^{*} 116\right)$. For the lowbush blueberry, the hue angle measured from the fruit flesh decreased in the regular atmosphere $\left(h^{*} 44\right)$ and in the LDPE film $\left(h^{*} 68\right)$, while it increased in the Xtend ${ }^{\circledR}$ film $\left(h^{*} 200\right)$ compared with the pre-storage $\left(h^{*} 90\right)$. For 'Northblue', the $h^{*}$ decreased in the regular atmosphere $\left(h^{*} 94\right)$ compared to the pre-storage $\left(h^{*} 105\right)$ and to the modified atmosphere package LDPE $\left(h^{*} 103\right)$.

There was a pronounced effect on the genetic difference when measuring the fruit flesh $\mathrm{a}^{*}$ values, indicating that the lowbush fruit flesh is redder in colour and that the 'Northblue' fruit is greener in colour. In addition, there was a significant difference between these two taxa concerning fruit flesh $b^{*}$ values, where 'Northblue' had a significantly higher $b^{*}$ value compared to the lowbush blueberry. Earlier studies have reported that the blueberry surface colour correlates well with the measurements of soluble solids, anthocyanins content, and titratable acid content [22,52]. Earlier research from Ballinger et al. [60] indicated that the surface colour is well correlated within the cultivar. For lowbush, the titratable acidity and the soluble solids content were higher in the Xtend ${ }^{\circledR}$ film compared to the initial value. That phenomenon was also observed for the half-highbush blueberry, where, in the Xtend ${ }^{\circledR}$ film, the titratable acidity and soluble solids values were higher compared to the pre-storage. These results had a significant interaction with the colour values, where the fruit surface colour with wax had a higher degree of redness in the $\mathrm{Xtend}^{\circledR}$ film compared to the pre-storage for both taxa. A similar trend was applicable for the hue angle, where, in Xtend ${ }^{\circledR}$ film, the $h^{*}$ values were higher 
compared with the initial value. For 'Northblue', the hue angle of the fruit without wax was also higher in the Xtend ${ }^{\circledR}$ package compared to the pre-storage. For lowbush, the same interaction occurred with the fruit flesh $\mathrm{h}^{*}$ measurements. For both blueberry taxa, the $\mathrm{X}$ tend ${ }^{\circledR}$ film had a pronounced effect on the fruit surface colour concerning without wax $C^{*}$ and on fruit flesh $C^{*}$ values.

\section{Conclusions}

Compared to regular atmosphere conditions, the $\mathrm{X}$ tend ${ }^{\circledR}$ package prolonged the postharvest the life of lowbush blueberries for 15 days and half-highbush blueberries for 9 days. LDPE package did not prolong the postharvest life of lowbush but extended the postharvest life of 'Northblue' for 9 days. The $\mathrm{CO}_{2}$ content was significantly higher in $\mathrm{Xtend}^{\circledR}$ film compared to the LDPE at the end of the storage. It can be concluded that lowbush blueberries need a higher $\mathrm{CO}_{2}$ content for retaining postharvest quality compared to half-highbush blueberry ('Northblue').

Both modified atmosphere packages had a negative effect on blueberry taste-related properties irrespectively of the taxa. The SSC:TA ratio of the blueberries in the modified atmosphere decreased both compared to the initial value and compared to the RA-stored blueberries by the end of storage.

The content of anthocyanins increased significantly with all storage conditions irrespectively of the taxa. However, for lowbush blueberries, both the modified atmosphere packages suppressed anthocyanin biosynthesis, whereas the 'Northblue' anthocyanins in MA were no different from RA.

The genetic differences were more important concerning fruit firmness, shrivelling, and decay. Both MA packages had an impact on the firmness and the shrivelling, but the half-highbush blueberry ('Northblue') fruits were firmer and less shrivelled compared to the lowbush.

Conclusively, both MA packages extended the postharvest life of 'Northblue' considerably, which is valuable information for producers. For lowbush blueberries, a higher $\mathrm{CO}_{2}$ than the LDPE could provide in the current study was needed in order to retain the external postharvest quality.

Further studies should be conducted to find out the metabolic differences of blueberry taxa and to match the respiration of the product with the permeation rates of the packages. The use of biodegradable films should be considered in order to ensure sustainability.

Author Contributions: Conceptualization, M.S., U.M.; methodology, M.S., U.M.; software, P.P.; formal analysis, M.S., A.K.; investigation, A.K.; resources, U.M.; data curation, M.S.; writing-original draft preparation, A.K., C.K., M.S.; writing-review and editing, U.M., P.P., M.S., C.K., A.K.; visualization, M.S., P.P.; supervision, M.S., U.M.; project administration, U.M.; funding acquisition, U.M.

Funding: This research received no external funding.

Acknowledgments: The Ministry of Rural Affairs which we are sincerely grateful financially supported this research. We would like to thank Toomas Jaadla (Marjasoo Farm) for his help in the blueberry experiment.

Conflicts of Interest: The authors declare that they have no conflict of interest. This article does not contain any studies with human participants or animals performed by any of the authors.

\section{References}

1. Skrovankova, S.; Sumczynski, D.; Mlcek, J.; Jurikova, T.; Sochor, J. Bioactive compounds and antioxidant activity in different types of berries. Int. J. Mol. Sci. 2015, 16, 24673-24706. [CrossRef] [PubMed]

2. Paniagua, A.C.; East, A.R.; Heyes, J.A. Interaction of temperature control deficiencies and atmosphere conditions during blueberry storage on quality outcomes. Postharvest Biol. Technol. 2014, 95, 50-59. [CrossRef]

3. Cappellini, R.A.; Ceponis, M.J.; Koslow, G. Nature and extent of losses in consumer-grade samples of blueberries in Greater New York. HortScience 1982, 17, 55-56.

4. Smittle, D.A.; Miller, W.R. Rabbiteye blueberry storage life and fruit quality in controlled atmospheres and air storage. J. Am. Soc. Hort. Sci. 1988, 113, 723-728.

5. Beaudry, R.M.; Cameron, A.C.; Shirazi, A.; Dostal-Lange, D.L. Modified-atmosphere packaging of blueberry fruit: Effect of temperature on package O2 and CO2. J. Am. Soc. Hort. Sci. 1992, 117, 436-441.

6. Chiabrando, V.; Giacalone, G. Studies on shelf life of 'Lateblue' highbush blueberries. Food Sci. Technol. Int. 2008, 14, 199-205. [CrossRef] 
7. Moggia, C.; Lobos, G.A.; Retamales, J.B. Modified atmosphere packaging in blueberries: Effect of harvest time and moment of bag sealing. Acta Hortic. 2014, 1017, 153-158. [CrossRef]

8. Alsmairat, N.; Contreras, C.; Hancock, J.; Callow, P.; Beaudry, R. Use of combinations of commercially relevant $\mathrm{O}_{2}$ and $\mathrm{CO}_{2}$ partial pressures to evaluate the sensitivity of nine highbush blueberry fruit cultivars to controlled atmospheres. HortScience 2011, 46, 74-79.

9. Hancock, J.; Gallow, P.; Serçe, S.; Hanson, E.; Beaudry, R. Effect of cultivar, controlled atmosphere storage, and fruit ripeness on the long-term storage and highbush blueberries. HortTechnology 2008, 18, 199-205.

10. Cappellini, R.A.; Stretch, A.W.; Maiello, J.M. Fungi associated with blueberries held at various storage times and temperatures. Phytopathology 1972, 62, 68-69. [CrossRef]

11. Sanford, K.A.; Lidster, P.D.; McRae, K.B.; Jackson, E.D.; Lawrence, R.A.; Stark, R.; Prange, R.K. Lowbush blueberry quality changes in response to mechanical damage and storage temperature. J. Am. Soc. Hort. Sci. 1991, 116, 47-51.

12. Giacalone, G.; Chiabrando, V. Problems and methods to improve the market-life of berry fruit. In Berries: Properties, Consumption and Nutrition Problems and Methods to Improve the Market-Life of Berry Fruit; Tuberoso, C., Ed.; Nova Science Publishers Inc.: New York, NY, USA, 2012; pp. 179-196.

13. Mattos, L.M.; Moretti, C.L.; Ferreira, M.D. Modified atmosphere packaging for perishable plant products. In Polypropylene; Dogan, F., Ed.; InTech: Vienna, Austria, 2012; pp. 95-110. [CrossRef]

14. Tarand, A.; Jaagus, J.; Kallis, A. Eesti Kliima Minevikus ja Tänapäeval; Tartu Ülikooli Kirjastus: Tartu, Estonia, 2013; p. 632. (In Estonian)

15. Paal, T.; Starast, M.; Noormets-Šanski, M.; Vool, E.; Tasa, T.; Karp, K. Influence of liming and fertilization on lowbush blueberry in harvested peat field condition. Sci. Hortic. 2011, 130, 157-163. [CrossRef]

16. Starast, M.; Karp, K.; Vool, E.; Paal, T.; Albert, T. Effect of NPK fertilization and elemental sulphur on growth and yield of lowbush blueberry. Agric. Food Sci. 2007, 16, 34-45. [CrossRef]

17. Tasa, T.; Starast, M.; Vool, E.; Moor, U.; Karp, K. Influence of soil type on half-highbush blueberry productivity. Agric. Food Sci. 2012, 21, 409-420. [CrossRef]

18. IUSS Working Group WRB. Word Reference Base for Soil Resources 2006, 2nd ed.; Word Soil Resources Reports 2006, No 103; FAO: Rome, Italy, 2006.

19. Infia TR80/58mm PET Punnet Base (+ BUBBLEPAD). 2015. Produce Packaging. Fresh Produce Packaging Solutions. Available online: http:/ / www.producepackaging.co.uk/products/trays-punnets-lids/plastic/ infia-tr8058mm-pet-punnet-base-\%28plus-bubblepad\%29.aspx (accessed on 6 May 2018).

20. Schotsmans, W.; Molan, A.; MacKay, B. Controlled Atmosphere Storage of Rabbiteye Blueberries Enhances Postharvest Quality Aspects; Institute of Food Nutrition and Human Health, Massey University: Auckland, New Zealand, 2007.

21. Giusti, M.M.; Wrolstad, R.E. Characterization and measurement of anthocyanins by UV-Visible spectroscopy. In Current Protocols in Food Analytical Chemistry; Giusti, M.M., Wrolstad, R.E., Eds.; John Wiley and Sons, Inc.: Hoboken, NJ, USA, 2001.

22. Kalt, W.; McRae, K.B.; Hamilton, L.C. Relationship between surface color and other maturity indices in wild lowbush blueberries. Can. J. Plant Sci. 1995, 75, 485-490. [CrossRef]

23. Song, Y.; Kim, H.K.; Yam, K.L. Respiration rate of blueberry in modified atmosphere at various temperatures. J. Am. Soc. Hort. Sci. 1992, 117, 925-929.

24. Peano, C.; Girgenti, V.; Baudino, C.; Giuggioli, N.R. Blueberry supply chain in Italy: Management, innovation and sustainability. Sustainability 2017, 9, 261. [CrossRef]

25. Valero, D.; Serrano, M. Postharvest Biology and Technology for Preserving Fruit Quality; CRC/Taylor \& Francis: Boca Raton, FL, USA, 2010; p. 287.

26. Fidler, J.C.; North, C.J. The effect of conditions of storage on the respiration of apples. I. The effects of temperature and concentrations of carbon dioxide and oxygen on the production of carbon dioxide and uptake of oxygen. J. Hortic. Sci. 1967, 42, 189-206. [CrossRef]

27. Kader, A.A. (Ed.) Post-Harvest Technology of Horticultural Crops, 3rd ed.; University of California, Division of Agriculture and Natural Resources Publication: Oakland, CA, USA, 2002; 535p.

28. Moor, U.; Põldma, P.; Tõnutare, T.; Moor, A.; Starast, M. The effect of modified atmosphere storage on the postharvest quality of the raspberry 'Polka'. Agron. Res. 2014, 12, 745-752.

29. Moor, U.; Mölder, K.; Põldma, P.; Tõnutare, T. Postharvest quality of 'Sonata', 'Honeoye' and 'Polka' strawberries as affected by modified atmosphere packages. Acta Hortic. 2012, 945, 55-62. [CrossRef] 
30. Giuggioli, N.R.; Girgenti, V.; Peano, C. Qualitative performance and consumer acceptability of starch films for the blueberry modified atmosphere packaging storage. Pol. J. Food Nutr. Sci. 2017, 67, 129-136. [CrossRef]

31. Hall, I.V.; Forsyth, F.R. Respiration rates of developing fruits of the lowbush blueberry. Can. J. Plant Sci. 1966, 47, 157-159. [CrossRef]

32. Prange, R.K.; Asiedu, S.K.; DeEll, J.R.; Westgarth, A.R. Quality of Fundy and Blomidon lowbush blueberries: Effects of storage atmosphere, duration and fungal inoculation. Can. J. Plant Sci. 1995, 75, 479-483. [CrossRef]

33. Ballington, J.R.; Ballanger, W.E.; Swallow, W.H.; Galletta, G.J.; Kushmann, L.J. Fruit quality characterization of 11 Vaccinium Species. J. Am. Soc. Hort. Sci. 1984, 109, 684-689.

34. Vicente, A.R.; Ortugno, C.; Rosli, R.; Powell, A.L.T.; Greve, L.C.; Labavitch, J.M. Temporal sequence of cell wall disassembly events in developing fruits. 2. Analysis of Blueberry (Vaccinium Species). J. Agric. Food Chem. 2007, 55, 4125-4130. [CrossRef] [PubMed]

35. Fava, J.; Alzamora, S.M.; Castro, M.A. Structure and nanostructure of the outer tangential epidermal cell wall in Vaccinium corymbosum L. (Blueberry) fruits by balanching, freezing-thawing and ultrasound. Food Sci. Technol. Int. 2006, 12, 241-251. [CrossRef]

36. Connor, A.M.; Luby, J.J.; Hancock, J.F.; Berkheimer, S.; Hanson, E.J. Changes in fruit antioxidant activity among blueberry cultivars during cold-temperature storage. J. Agric. Food Chem. 2002, 50, 893-898. [CrossRef] [PubMed]

37. Edwards, T.W., Jr.; Sherman, W.B.; Sharpe, R.H. Evaluation and inheritance of fruit color, size, scar, firmness and plant vigor in blueberry. HortScience 1974, 9, 20-22.

38. Finn, C.E.; Luby, J.J. Inheritance of fruit quality traits in blueberry. J. Am. Soc. Hort. Sci. 1992, 117, 617-621.

39. Ehlenfeldt, M.K.; Martin, R.B., Jr. A survey of fruit firmness in highbush blueberry and species-introgressed blueberry cultivars. HortScience 2002, 37, 386-389.

40. Giongo, L.; Poncetta, P.; Loretti, P.; Costa, F. Texture profiling of blueberries (Vaccinium spp.) during fruit development, ripening and storage. Postharvest Biol. Technol. 2013, 76, 34-39. [CrossRef]

41. Almenar, E.; Samsudin, H.; Auras, R.; Harte, B.; Rubino, M. Postharvest shelf life extension of blueberries using a biodegradable package. Food Chem. 2008, 110, 120-127. [CrossRef] [PubMed]

42. Wang, S.Y.; Chen, C.-T.; Yin, J.-J. Effect of allyl isothiocyanate on antioxidants and fruit decay of blueberries. Food Chem. 2010, 120, 199-204. [CrossRef]

43. Echeverría, G.V.; Cañumir, J.V.; Serri, G.H. Postharvest behaviour of highbush blueberry fruits cv. O’Neal cultivated with different organic fertilization treatments. Chil. J. Agric. Res. 2009, 69, 391-399. [CrossRef]

44. Abeles, F.B.; Morgan, P.W.; Saltveit, M.E., Jr. Ethylene in Plant Biology, 2nd ed.; Academic Press: San Diego, CA, USA, 1992; p. 414. [CrossRef]

45. Zheng, Y.; Yang, Z.; Chen, X. Effect of high oxygen atmospheres on fruit decay and quality in Chinese bayberries, strawberries and blueberries. Food Control 2008, 19, 470-474. [CrossRef]

46. Jackson, E.D.; Sanford, K.A.; Lawrence, R.A.; McRae, K.B.; Stark, R. Lowbush blueberry quality changes in response to prepacking delays and holding temperatures. Postharvest Biol. Technol. 1999, 5, 117-126. [CrossRef]

47. Kalt, W.; McDonald, J. Chemical composition of lowbush blueberry cultivars. J. Am. Soc. Hort. Sci. 1996, 121, 142-146.

48. Duan, J.; Wu, R.; Strik, B.C.; Zhao, Y. Effect of edible coatings on quality of fresh blueberries (Duke and Elliott) under commercial storage conditions. Postharvest Biol. Technol. 2011, 59, 71-79. [CrossRef]

49. Gonçalves, C.F.; Guiné, R.P.F.; Gonçalves, F.; Costa, D.V.T.A. Physical-Chemical Properties of Blueberry as Influenced by Production and Conservation Processes. International Conference on Engineering, University of Beira Interior, Covilhã, Portugal; 2-4 December 2015. Available online: http:/ / repositorio. ipv.pt/bitstream/10400.19/2993/1/2015_Covilha_ICEUBI_Ata_Daniela_Mirtilo\%20Prop.pdf (accessed on 12 June 2018).

50. Beaudry, R. Blueberry quality characteristics and how they can be optimized. In Annual Report of the Michigan State Horticultural Society, 122nd ed.; Michigan State Horticultural Society: East Lansing, MI, USA, 1992; pp. 140-145.

51. Albrigo, L.E.; Hall, I.V. Waxes and other surface characteristics of fruits and leaves of native Vaccinium elliotti Chapm. J. Am. Soc. Hort. Sci. 1980, 105, 230-235.

52. Kushman, L.I.; Ballinger, W.E. Relation of quality indices of individual blueberries to photoelectric measurement of anthocyanin content. J. Am. Soc. Hort. Sci. 1975, 100, 561-564. 
53. Duarte, C.; Guerra, M.; Daniel, P.; Camelo, A.L.; Yommi, A. Quality changes of highbush blueberries fruit stored in CA with different $\mathrm{CO}_{2}$ levels. J. Food Sci. 2009, 74, 154-159. [CrossRef] [PubMed]

54. Faria, A.; Oliveira, J.; Neves, P.; Gameiro, P.; Santos-Buelga, C.; de Freitas, V.; Mateus, N. Antioxidant properties of prepared blueberry (Vaccinium myrtillus) extracts. J. Agric. Food Chem. 2005, 53, 6896-6902. [CrossRef] [PubMed]

55. Sinelli, N.; Spinardi, A.; Egidio, V.D.; Mignani, I.; Casiraghi, E. Evaluation of quality and nutraceutical content of bluberries (Vaccinium corymbosum L.) by near and mid-infrared spectroscopy. Postharvest Biol. Technol. 2008, 50, 31-36. [CrossRef]

56. Ayhan, Z.; Eştürk, O.; Müftüoğlu, F. Effects of coating, modified atmosphere (MA) and plastic film on the physical and sensory properties of apricot. Acta Hortic. 2010, 876, 143-150. [CrossRef]

57. Saftner, R.; Polascock, J.; Ehlenfeldt, M.K.; Vinyar, B. Instrumental and sensory quality characteristics of blueberry fruit from twelve cultivars. Postharvest Biol. Technol. 2008, 49, 19-26. [CrossRef]

58. Eum, H.L.; Hong, S.C.; Chun, C.; Shin, S., II; Lee, B.Y.; Kim, H.K.; Hong, S.J. Influence of temperature during transport on shelf-life quality of highbush blueberries (Vaccinium corymbosum L. cvs. Bluetta, Duke). Hort. Environ. Biotechnol. 2013, 54, 123-133. [CrossRef]

59. Routray, W.; Orsat, V. Blueberries and their anthocyanins: Factors affecting biosynthesis and properties. Compr. Rev. Food Sci. 2011, 10, 303-320. [CrossRef]

60. Ballinger, W.E.; Maness, E.P.; Galletta, G.J.; Kushman, L.J. Anthocyanin of ripe fruit of a pink-fruited hybrid of highbush blueberries, Vaccinium corymbosum L. J. Am. Soc. Hort. Sci. 1972, 97, 381-384.

(C) 2018 by the authors. Licensee MDPI, Basel, Switzerland. This article is an open access article distributed under the terms and conditions of the Creative Commons Attribution (CC BY) license (http://creativecommons.org/licenses/by/4.0/). 